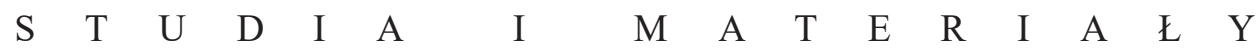

Przeszłość Demograficzna Polski 40 (2018)

Poland's Demographic Past 40 (2018)

DOI: $10.18276 /$ pdp.2018.40-03

Oksana Kovalenko

ORCID: https://orcid.org/0000-0003-0980-2870

National Academy of Sciences of Ukraine, Ceramology Branch of the Ethnology Institute

email: kovksana@gmail.com

\title{
Family Structures and Population of Craftsman Households in Cossack Ukraine in the Second Half of the $18^{\text {th }}$ Century
}

\section{Struktura rodziny i populacji gospodarstw domowych rzemieślników na kozackiej Ukrainie w drugiej połowie XVIII wieku}

\begin{abstract}
This article focuses on the history of the family and households in eighteenth-century Ukraine. The aim of the article is to observe the demographical characteristics of craftsman guild families and households in the Cossack Hetmanate (an autonomous Cossack territory situated on the Left Bank of the Dnieper River) in the cities of Poltava, Pereiaslav and Nizhyn. Calculations are based on the General Description of the Left-bank Ukraine of 1765-1766. In the article, population size indicators for the artisan households and their families are established. Family household types are defined on the basis of works by Peter Lasslett and Cezary Kuklo. Craft specialization is taken into account for clarifying the influence of the
\end{abstract}

\begin{abstract}
Abstrakt
Artykuł skupia się na historii rodziny i gospodarstw domowych w osiemnastowiecznej Ukrainie. Ma na celu ukazanie cech demograficznych rodzin rzemieślników cechowych i gospodarstw domowych w Hetmanacie Kozackim (autonomiczne terytorium Kozaków położone na lewym brzegu Dniepru) na przykładzie miast Połtawa, Pereiasław i Niżny. Obliczenia opierają się na Generalnym Opisie Lewobrzeżnej Ukrainy z lat 1765-1766. W artykule ustalono wskaźniki wielkości populacji gospodarstw domowych rzemieślników i wielkości ich rodzin. Typy rodzinnych gospodarstw domowych określono na podstawie prac Petera Lassletta i Cezarego Kuklo. Specjalizacja rzemiosła jest brana pod uwagę przy wyjaśnianiu
\end{abstract}


occupation on the size of the households and family household types. The calculations were made separately for the crafts that were the most widespread in all the cities: weaving, blacksmithing, tailoring, shoemaking and butchering.

\section{Keywords}

Cossack Hetmanate, household, family, craftsmen, guild, apprenticeship, left bank of the Dnieper River, historical demography wpływu zajęć rzemieślniczych na wielkość gospodarstw domowych i rodzinnych typów gospodarstw domowych. Obliczenia wykonano osobno dla rzemiosł, które były najbardziej rozpowszechnione we wszystkich miastach: tkactwa, kowalstwa, szewstwa i rzeźnictwa.

\section{Słowa kluczowe}

Hetmanat kozacki, gospodarstwo domowe, rodzina, rzemieślnicy, gildia, nauka rzemiosła, lewy brzeg Dniepru, demografia historyczna

\section{Introduction}

Crafts formed the basis of pre-industrial economics. The main division of the pre-modernist "European city" (using the construction of ideal types by Max Weber) was the separation of a city from its outskirts, which meant the allocation of an area where special city rights functioned. This coincided with the rise and formation of the guild system. The peculiarities of city rights, arrangements between regimental ${ }^{1}$ and city administrations, and the everyday life of guild craftsmen in the Cossack Hetmanate are still almost unknown. This range of issues can be solved with the help of historic demographic research into the artisan population. Nevertheless, specialist research into the Hetmanate craftsmen class has not yet been carried out.

This article covers the regional and professional specifics of the structure of craftsman households, the types of family organization, and the size of craftsman households and families. We made a comparison of the indexes for the most eastern European cities with Magdeburg Rights with the indexes calculated for cities in Western European countries and Poland. The demographic information on "people of corporation" made it possible to compare the Hetmanate with its European counterparts and allowed us to specify the term "burghers" in the Hetmanate in the second half of the $18^{\text {th }}$ century.

\footnotetext{
${ }^{1}$ Regiment - a historical administrative, territorial, military and judicial unit of the country's subdivision in the Cossack Hetmanate. Cities were the location of the regiment administration and city government.
} 
This article studies the composition of the households and family structures of craftsmen living in the cities of Poltava, Pereiaslav and Nizhyn, Central Ukraine, in the second half of the eighteenth century. Calculations are based on the General Description of the Left-bank Ukraine of 1765-1766 (or Rumyantsev Census) ${ }^{2}$, a population and household census conducted on the orders of Catherine the Great by the Second Little Russian Collegium ("Malorosiiska kolehiia") headed by general gubernator Pyotr Rumyantsev. Many researchers have already noted the significance of this source. In particular, the data from this document were analyzed by Igor Kovaljsjkyj ${ }^{3}$ in terms of their informational potential and were used permanently in works on social economic history ${ }^{4}$; they were also used for the demographic characterizing of the Hetmanate regimental cities of the second half of the $18^{\text {th }}$ century. ${ }^{5}$

The aim of the Rumyantsev Census was to define the population structure according to the following categories: the clergy, the military (Cossacks) and non-Cossacks: burghers ("mishchany"), craft artisans ("tsekhovi") and peasants without Cossack status ("pospolyti"), and to obtain information on their property, activities, profits, the balance between private and state lands, trade intensity etc. ${ }^{6}$ The census was carried out by way of a sequential street-by-street walk-round of all the city buildings and private households. The household was the main tax unit in the fiscal system of Hetman Ukraine.

The draftsmen of the Rumyantsev Census noted all the households according to three types: "dvor" - yard, "bezdvorna hata" - yardless houses and "pidvarok" - farms. The content of this source and previous historic research ${ }^{7}$ allows us to

2 "Rumjancevsjkyj opys m. Nizhyna 1766 r." Nizhynsjka starovyna: zbirnyk reghionaljnoji istoriji ta pam' jatkoznavstva 10 (2008), 7: 3-197; Central State Historical Archive of Ukraine in Kiev (henceforth: CSHAUK), Fund 57, Register 1, Case 278: 1-303; CSHAUK, Fund 57, Register 2, Case 1: 1-390; Yuriy Voloshyn, ed., Poltava City in Rumyantsev Register of Little Russia in 1765-1769 (Kyiv: Our time, 2012), 44-505.

${ }^{3}$ Igor Kovaljsjkyj, "Gheneraljnyj opys 1765-1769 rr. - dzherelo dlja vyvchennja socialjnoekonomichnykh vidnosyn na Livoberezhnij Ukrajini”, Ukrajinsjkyj istorychnyj zhurnal 2 (1962): 97-103.

${ }^{4}$ Oleksiy Putro, "Gheneraljnyj opys $1765-1769$ pp. jak dzherelo dlja vyvchennja socialjnoekonomichnykh vidnosyn na Livoberezhnij Ukrajini u drughij polovyni XVIII st.” (in Ukrainian), Ukrajinsjkyj istorychnyj zhurnal 7 (1982): 143-149.

${ }^{5}$ Ihor Serdjuk, "Rumjancevsjkyj opys Malorosiji jak dzherelo vyvchennja demoghrafichnykh kharakterystyk mist Ghetjmanshhyny”, Istorychna pam' jatj 3 (2008): 144-152.

${ }^{6}$ Ihor Serdiuk, Polkovykh horodov obyvateli: istorko-demohrafichna kharakterystyka miskoho naselennia Hetmanshchyny druhoi polovyny XVIII st. (Poltava: ASMI, 2011), 30.

${ }^{7}$ We use the term "yard", as more relevant to the sources and according to: Yuriy Voloshyn, "Household Composition and Family Structures of Ukrainian Cossacks in the Second Half of the Eighteenth Century", The History of the Family 20 (2015), 1: 143; Grygoriy Maksimovich, Deyatelnost Rumyantseva-Zadunayskogo po upravleniyu Malorossiey (Nezhin: Typography of Melenevskiy, 1913), 317. 
be able to define a "yard" as a single plot with living accommodation and farm buildings, where people related both by blood and united by labor relations, common duties, work, taxes etc. lived. The "yardless houses" differed from other households because they did not have a plot of land ${ }^{8}$. The third type of a household was a "farm". This term was borrowed from the practice of $18^{\text {th }}$-century Russia to identify a part of a city housing stock, pointing to a plot of land with houses and farm buildings, whose owner mainly lived in a different place, but who settled his/her servants or waged workers (in other words - a group of people not united by kin or labor relations) in that place?

According to the correct terminology, by "family" we mean all blood relatives, and by "household", blood relatives and servants, co-neighbors and other non-kin living together ${ }^{10}$. Taking into consideration these differences, calculating household size in this article was conducted separately for the families of household owners and separately for other household residents.

The calculation of household structure and methodology of the description of craftsmen yards were based on works by Peter Laslett ${ }^{11}$. Fieldwork done by Mykola Szoltysek ${ }^{12}$, Cezary Kuklo ${ }^{13}$, Yuriy Voloshyn ${ }^{14}$, Ihor Serdiuk ${ }^{15}$ on calculating households and specifying family structure was used for making our analysis.

The three cities chosen were separate regimental centers, located in different parts of the Hetmanate. A part of the city population was constituted by craftsmen who did not belong to a separate category but were members of different

${ }^{8}$ Maksimovich, Deyatelnost, 317; Arnold Perkovskiy, "O lyudnosti ukrainskogo dvora i velichine semi vo vtoroy polovine XVIII veka (po materialam Rumyantsevskoy opisi i tserkovnoy statistiki)" Problemy istoricheskoy demografii SSSR (1977): 105.

${ }^{9}$ Oksana Kovalenko, Poltava XVII-XVIII st. (Kyiv: PP Oleh Filiuk, 2015), 115.

${ }^{10}$ Voloshyn, "Household", 141.

${ }^{11}$ Peter Laslett, "Family and Household as Work and Kin Group: Areas of Traditional Europe Compared", in: Family Forms in Historic Europe, eds. Richard Wall, Jean Robin, Peter Laslett (Cambridge: Cambridge University Press, 1983), 513-564.

${ }^{12}$ Mikołaj Szołtysek, "Three Kinds of Preindustrial Household Formation System in Historical Eastern Europe: A Challenge to Spatial Patterns of the European Family". The History of the Family 13 (2008), 3: 225-257.

${ }^{13}$ Cezary Kuklo, Demografia Rzeczypospolitej przedrozbiorowej (Warszawa: Wydawnictwo DIG, 2009), 149-155, 174-194.

${ }^{14}$ Yuriy Voloshyn, Kozaky i pospolyti. Miska spilnota Poltavy druhoi polovyny XVIII st. (Kyiv: K.I.S., 2016), 27-54, 96-101; Yuriy Voloshyn, Oleksandr Sakalo, "Naselenist domohospodarstv i struktura rodyn", in: Ukrainskyi Hetmanat: narysy istorii natsionalnoho derzhavotvorennia XVII-XVIII st., eds. Valeriy Smolii, Olena Bachynska, Viktor Horobets, Oleksandr Hurzhii, Valentyna Matiakh, Yuriy Mytsyk, Valeriy Stepankov, Yaroslav Fedoruk, Taras Chukhlib, book 2 (Kyiv: Instytut istorii Ukrainy, 2018), 274-303; Voloshyn, "Household", 141-157; Yuriy Voloshyn, Rozkolnytski slobody na terytorii Pivnichnoi Hetmanshchyny u XVIII st. (istoryko demohrafichnyi aspekt) (Poltava: ASMI, 2005), 213-254.

${ }^{15}$ Serdiuk, Polkovykh horodov obyvateli, 174-199. 
social classes: citizens, Cossacks, "pospolyti”, even "pidsusidky" (co-neighbors). The co-neighbours ("pidsusidky") were Cossacks, peasants or citizens who had lost their households and came to live with rich owners, not working for a living but working for the owners of the household where they lived ${ }^{16}$. Craftsmen, representatives of different social classes, belonged to city guilds or worked independently. There is information in the 1766 Rumyantsev Census of Nizhyn, with about 5,086 inhabitants (2,589 men) including 2,472 burghers, and 541 Cossacks $^{17}$. The total number of inhabitants who lived in the city and were recorded with a mention of their profession is 282 (it is worth mentioning that the source did not always specify the kind of craft of the household owner, which is why the number of artisans could hypothetically be higher). Another 1,799 inhabitants lived in Pereiaslav in 1766, while 7,523 people resided in Poltava, the easternmost city with Magdeburg Rights ${ }^{18}$. The total number of people in artisan households for that period was $1,483,541$, and 1,035 respectively. The research is focused on them. Information on 1,005 households is also added to the analysis.

Most craftsmen lived in their own yards. Occurrences of guild craftsmen living on farms were not recorded in any city, while $4.9 \%$ of artisan families in Poltava, $18.7 \%$ in Pereiaslav, and $0.8 \%$ in Nizhyn lived in yardless houses. Craftsmen settled in a dispersive manner, i.e., they lived on different streets in the city, not forming separate "artisan" districts. Solid artisan blocks or guild houses were absent there, in contrary to European cities. Artisans' yards included from one to three residential houses, a pantry, and other household outbuildings. The calculation has shown that most craftsmen lived in the most simply constructed yards, which included only a house or a house with a pantry. All masters used their home as a place of work. Their workshops could be located inside the houses or in the household outbuildings, and on the owners' estates.

In terms of the specifics of the buildings in the yards according to the specialization of the owner's craft, the largest number of residential and commercial premises was located in the yards of shoemakers and cutters. The latter also possessed richer yards. Smiths, whose profession demanded special buildings and a particular workplace, owned only one house without additional outbuildings in most cases. They, along with potters, built their objects (kilns and smithies) far from the city's main residential area, on separate streets close to the city walls or in the suburbs. The biggest and richest yards consisting of three houses, two pantries, a storehouse or two owner's houses, one house for servants, a pantry, a stable and

\footnotetext{
${ }^{16}$ Voloshyn, Kozaky, 113.

${ }^{17}$ Serdiuk, Polkovykh horodov obyvateli, 78, 176, 185.

${ }^{18}$ Serdiuk, Polkovykh horodov obyvateli, 77, 78; Voloshyn, Kozaky, 84.
} 
a storehouse, belonged to Cossacks, innkeepers and merchants, who were obviously members of guilds, although they probably earned a living by trading ${ }^{19}$.

\section{Household populations}

Demographic research into European cities has proved that, despite a more recent assumption, the city household had a small size in the second half of the $18^{\text {th }}$ century $^{20}$. So what was the population size of artisan households and the size of their families? An evident lack of calculations for burgher households, separate craftsman yards in the Hetmanate (excluding Poltava) and an absence of population analysis for craftsman yards belonging to different specialties, caused additional problems. Here, I would like to mention that all previous calculations were made according to the following groups: clergy, Cossacks, peasants, or burghers. Though Hetmanate cities had specific inhabitants, their own social structure and governmental dualism (there were both magistrates and regimental or "sotnia" administrations), burghers were quite socially different. Guild craftsmen, who were traditionally considered to be burghers, were subordinate to the magistrate, with Cossacks subject to regimental administration. This resulted in the regimental chancery seeking to limit the category of burghers to merchants only and controversy with juridical subordination in the first half of the $18^{\text {th }}$ century. They wanted to separate artisans from the burgher category, limiting to it mostly small traders and merchants ${ }^{21}$.

Table 1. Population of craftsman households in Poltava

\begin{tabular}{lccccc}
\hline \multirow{2}{*}{\multicolumn{1}{c}{ Craft specialties }} & \multirow{2}{*}{$\begin{array}{c}\text { Number } \\
\text { of households }\end{array}$} & \multicolumn{2}{c}{ Size of families } & \multicolumn{2}{c}{ Household population } \\
\cline { 3 - 6 } & & number & average & number & average \\
of persons & size & of persons & size \\
\hline Weavers & 15 & 69 & 4.6 & 78 & 4.8 \\
Smiths & 27 & 125 & 4.6 & 145 & 5.4 \\
Tailors & 36 & 179 & 5.0 & 240 & 6.7 \\
Shoemakers & 43 & 207 & 4.8 & 270 & 6.3 \\
Butchers & 24 & 132 & 5.5 & 157 & 6.4 \\
Others & 23 & 98 & 4.3 & 145 & 6.3 \\
\hline Total (all craftsman yards) & 168 & 810 & 4.8 & 1035 & 5.9 \\
\hline
\end{tabular}

Source: Voloshyn, Poltava City, 44-505.

19 "Rumjancevsjkyj opys", 123, 124.

${ }^{20}$ Kuklo, Demografia, 149-154; Joanna Schmidt, "Wielkość i struktura gospodarstw domowych w Siemiatyczach w 1807 roku”, Przeszłość Demograficzna Polski 39 (2017): 151-153.

${ }^{21}$ Pylyp Klymenko, Misto y terytoriia za Hetmanshchyny 1654-1764 (Kyiv: UAN, 1926), 28; Kovalenko, Poltava, 39. 
The average population index for craftsman yards in Poltava according to a church recording of the population in 1775, counted by Yuriy Voloshyn, was: the number of people in families - 706, average index -4.6, with the number of people in households -914 , average index $-6.9^{22}$.

Table 2. Population of craftsman households in Pereiaslav

\begin{tabular}{|c|c|c|c|c|c|}
\hline \multirow[b]{2}{*}{ Craft specialties } & \multirow[b]{2}{*}{$\begin{array}{c}\text { Number } \\
\text { of households }\end{array}$} & \multicolumn{2}{|c|}{ Size of families } & \multicolumn{2}{|c|}{ Household population } \\
\hline & & $\begin{array}{c}\text { number } \\
\text { of persons }\end{array}$ & $\begin{array}{c}\text { average } \\
\text { size }\end{array}$ & $\begin{array}{l}\text { number } \\
\text { of persons }\end{array}$ & $\begin{array}{l}\text { average } \\
\text { size }\end{array}$ \\
\hline Weavers & 7 & 35 & 5.00 & 35 & 5.0 \\
\hline Smiths & 6 & 19 & 3.20 & 35 & 5.8 \\
\hline Tailors & 13 & 50 & 3.80 & 60 & 4.8 \\
\hline Shoemakers & 34 & 155 & 4.50 & 200 & 5.9 \\
\hline Butchers & 4 & 14 & 3.50 & 15 & 3.7 \\
\hline Other specialties & 33 & 161 & 4.90 & 196 & 5.9 \\
\hline Total (all craftsman yards) & 97 & 434 & 4.15 & 541 & 5.2 \\
\hline
\end{tabular}

Source: CSHAUK, Fund 57, Register 1, Case 278: 2-303.

Table 3. Population of craftsman households in Nizhyn

\begin{tabular}{|c|c|c|c|c|c|}
\hline \multirow[b]{2}{*}{ Craft specialties } & \multirow[b]{2}{*}{$\begin{array}{c}\text { Number } \\
\text { of households }\end{array}$} & \multicolumn{2}{|c|}{ Size of families } & \multicolumn{2}{|c|}{ Household population } \\
\hline & & $\begin{array}{c}\text { number } \\
\text { of persons }\end{array}$ & $\begin{array}{l}\text { average } \\
\text { size }\end{array}$ & $\begin{array}{l}\text { number } \\
\text { of persons }\end{array}$ & $\begin{array}{l}\text { average } \\
\text { size }\end{array}$ \\
\hline Weavers & 10 & 72 & 7.2 & 78 & 7.8 \\
\hline Smiths & 10 & 49 & 4.9 & 68 & 6.8 \\
\hline Tailors & 18 & 85 & 4.7 & 104 & 5.8 \\
\hline Shoemakers & 49 & 233 & 4.8 & 301 & 6.1 \\
\hline Butchers & 6 & 23 & 3.8 & 27 & 4.5 \\
\hline Others specialties & 148 & 666 & 4.5 & 905 & 6.1 \\
\hline Total (all craftsman yards) & 241 & 1128 & 5.0 & 1483 & 6.2 \\
\hline Total (all Nizhyn yards) & 770 & 2253 & 4.6 & 5086 & 6.6 \\
\hline
\end{tabular}

Note: The average size of yardless house populations is 3.5 and 5.1, respectively.

Source: "Rumjancevsjkyj opys", 3-197.

Family size. The calculations show that the size of craftsman families was small and was in total 4.5 for the three cities: Pereiaslav -4.1 , Poltava $-4.3^{23}$,

\footnotetext{
${ }^{22}$ Voloshyn, Kozaky, 180.

${ }^{23}$ Voloshyn, Kozaky, 183.
} 
Nizhyn - 5.0 (tables 1-3). The lowest figures was in Pereiaslav, with the highest in Nizhyn. The figure for Nizhyn differed from the other two cities with its higher-than-average family size. Analysis of the craftsman family size according to specialties does not show any regularity. The average data shows that families with the highest number of members were those of weavers. However, every city and specialty has its own unique peculiarities. In this case, the largest Poltava families were those of butchers, but they were the least numerous in Nizhyn at that time. In contrast, the largest families in Nizhyn were those of weavers, while they were the least numerous in Poltava. Shoemakers were leaders in Pereiaslav, while smiths had the smallest families. The size index for shoemakers' families $-4.5-4.8$ - corresponds with the size of shoemakers' families in Lviv, which was $4.6^{24}$.

Household population. Workers, apprentices, journeymen, relatives and other people (co-neighbors etc.) could live in a household with a family. In Poltava, co-neighbors lived in only 2 guild craftsmen yards (according to Yuriy Voloshyn's calculations, this is $2.3 \%$ of the total number of household owners who had co-neighbors living with them ${ }^{25}$ ), in Pereiaslav, 3 yards, and in Nizhyn, 9 yards. Co-neighbors lived mainly in nobles' yards, while journeymen and apprentices could live in the yards of craftsmen as a result of the guild structure. Journeymen were not separately mentioned in the Rumyantsev Census. Therefore, a part of the "servants" were probably journeymen. Apprentices were more numerous, from one to four, but in most cases only one apprentice lived in a craftsman's family at one time. For example, in Nizhyn, $60.8 \%$ of the masters taught one apprentice, and some $27.5 \%$ taught two.

This is why the size of the household population is higher, at 5.8; in Pereiaslav 5.2, in Nizhyn, 6.2, and in Poltava 5.9. ${ }^{26}$. At first glance, it would appear that a higher number of people should have lived in artisans' households than in other city yards because, apart from the family, workers, apprentices, servants, relatives and others could also live there. However, in all cases artisans' yards were smaller than the average city index.

Household size for artisans of different professions shows that, despite regional diversity, butchers' yards were not highly populated (3.7 people). The most inhabitants lived in weavers' and shoemakers' yards (average 6.0 people). An unexpectedly high index was in smith yards, because professions such as smiths, potters, and wheelwrights needed a separate space for working. The presence

${ }^{24}$ Myron Kapralj, Ljudy korporaciji: Ljvivsjkyj shevsjkyj cekh u XVIIXVIII st. (Ljviv: ProstirM, 2012), 197.

${ }^{25}$ Voloshyn, Kozaky, 113.

${ }^{26}$ Voloshyn, "Household", 152-153. 
of separately placed smithies in all the cities and the remarkable yard population proves that smiths did not work at home. In contrast, he populations of the potters' households were a little smaller (for example, 5.5 in Poltava). Potters did not have separate workshops and used space in the living accommodation or outbuildings for autumn and winter work.

To verify the source data and the validity of our calculations from tables 1-3, the Pearson correlation coefficient was applied. As a result, the data obtained is $0.98-0.99$, which indicates a direct, close relationship between the indicators of infertility and the number of artisan family members or the total number of households. And, therefore, it is possible to consider the data from the sources and calculations to be probable, with a high degree of reliability. In addition, the indicators were calculated using the chi-squared test. It was established that the rate of the inactivity depended on the number of residents, and not on the number of households (in Poltava, $0.11 \%, 78.2 \%$, in Pereyaslav, $32.7 \%, 39.3 \%$ of the total variability). In the case of Nizhyn, we see another result of 5.03\%, and 3.4\%, that is, a low inverse relationship between variables, because in this city, with an average closer to the average rate of density, there was a larger number of households.

Let us compare the data from these three cities with others. Arnold Perkovskyi's calculation of the average size of all Kyiv Eparchy families (urban and rural inhabitants) in 1776 gave a rate of 4.6 people $^{27}$. Yuriy Voloshyn's research on Poltava inhabitants in 1775 demonstrates a similar situation - the population of the average yard was 7.3, with the size of the families 4.7. ${ }^{28}$ At the same time, the population of rural households in the Hetmanate was rather high, at 10.4 for the villages of Lubny Regiment, and 8.9 in Starodub Regiment ${ }^{29}$. According to Dmytro Kazimirov's statistics, the average household size in Mena, a town in Chernihiv Regiment, was 12 people $^{30}$. This was obviously caused by a need for an expansion in the number of workers for cultivating land. According to data provided by Cezary Kuklo, the average family and household sizes in Poland approached the size of the Hetmanate. In particular, artisan families in Dobre, Warmia (1695) were made up of 5.0 people, and the average size of bourgeois households in Cracow (1791) was 4.5 people $^{31}$.

\footnotetext{
${ }^{27}$ Perkovskiy, "O lyudnosti”, 106.

${ }^{28}$ Voloshyn, Kozaky, 183.

${ }^{29}$ Voloshyn, Sakalo, "Naselenist"297, 298.

${ }^{30}$ Dmytro Kazimirov, Features of forming and developing company structures in Hetmanate in the second half of the 17-18 century (based on materials of Mena's Company/Squadron of Chernihiv Regiment), PhD Thesis (Kyiv: The Institute of the History of Ukraine of the National Academy of Sciences of Ukraine, 2012), 98.

${ }^{31}$ Kuklo, Demografia, 361.
} 


\section{Family household types}

In early modern times, the possibility to inherit a craft was a very important aspect of a guild's organization. When joining the guild, a master craftsman gave his children this right automatically if they followed his profession. This is explained by the laws of that time. Cases of fathers and sons or brothers with the same profession living together did occur, but they were rather rare. Even if they followed their father's profession, sons always preferred to live separately, creating their own new household. Family classification illustrates this distinctively. Source limitations do not always make it clear if a person belonged to a guild or not, which is why representatives from all social classes, noted with profession, including co-neighbors, were included ${ }^{32}$.

According to P. Laslett, five main types of family households can be defined:

I) The single-person household (solitaries);

II) The non-nuclear household (no family), where members are connected by family relations, but do not create a nuclear core;

III) The nuclear family household, which consists of married couple with or without children;

IV) A household is considered extended (extended family household) if in addition to immediate family, close relatives live in the same household;

V) The multiple family household, which consists of several nuclear families $^{33}$.

${ }^{32}$ In cases where artisans' co-neighbors lived in the yards, where their owners or other coneighbors lived, they were not included in the classification. As their number is very low, it does not influence the selection. In cases where only craftsmen co-neighbors lived in the yards, their families were classified according to the standard scheme.

${ }^{33}$ Laslett, "Family", 36-139. 
Table 4. Structure of craftsman households in Poltava, Pereiaslav and Nizhyn according to family types (by Peter Laslett's classification)

\begin{tabular}{|c|c|c|c|c|c|}
\hline \multirow{2}{*}{$\begin{array}{c}\text { Craft } \\
\text { specialties }\end{array}$} & \multirow{2}{*}{ Type of number } & \multirow{2}{*}{ Family types } & \multicolumn{3}{|c|}{ Town } \\
\hline & & & Poltava & Pereiaslav & Nizyn \\
\hline 1 & 2 & 3 & 4 & 5 & 6 \\
\hline \multirow{10}{*}{ Weavers } & \multirow{2}{*}{$\begin{array}{l}\text { absolute number } \\
\%\end{array}$} & \multirow{2}{*}{ I } & - & - & - \\
\hline & & & - & - & - \\
\hline & \multirow{2}{*}{$\begin{array}{l}\text { absolute number } \\
\%\end{array}$} & \multirow{2}{*}{ II } & - & - & 1 \\
\hline & & & - & - & 9.1 \\
\hline & \multirow{2}{*}{$\begin{array}{l}\text { absolute number } \\
\%\end{array}$} & \multirow{2}{*}{ III } & 11 & 6 & 3 \\
\hline & & & 71.4 & 85.7 & 27.3 \\
\hline & \multirow{2}{*}{$\begin{array}{l}\text { absolute number } \\
\%\end{array}$} & \multirow{2}{*}{ IV } & 2 & - & 2 \\
\hline & & & 14.3 & - & 18.2 \\
\hline & \multirow{2}{*}{$\begin{array}{l}\text { absolute number } \\
\%\end{array}$} & \multirow{2}{*}{ V } & 2 & 1 & 5 \\
\hline & & & 14.3 & 14.3 & 45.4 \\
\hline \multirow{10}{*}{ Smiths } & \multirow{2}{*}{$\begin{array}{l}\text { absolute number } \\
\%\end{array}$} & \multirow{2}{*}{ I } & - & - & - \\
\hline & & & - & - & - \\
\hline & \multirow{2}{*}{$\begin{array}{l}\text { absolute number } \\
\%\end{array}$} & \multirow{2}{*}{ II } & - & 1 & - \\
\hline & & & - & 16.7 & - \\
\hline & absolute number & \multirow{2}{*}{ III } & 16 & 5 & 8 \\
\hline & $\%$ & & 59.3 & 83.3 & 80 \\
\hline & absolute number & \multirow{2}{*}{ IV } & 4 & - & - \\
\hline & $\%$ & & 14.8 & - & - \\
\hline & absolute number & \multirow{2}{*}{$\mathrm{V}$} & 7 & - & 2 \\
\hline & $\%$ & & 25.9 & - & 20 \\
\hline \multirow{10}{*}{ Tailors } & absolute number & \multirow{2}{*}{ I } & - & - & 1 \\
\hline & $\%$ & & - & - & 5.9 \\
\hline & absolute number & UI & 1 & 1 & - \\
\hline & $\%$ & II & 2.6 & 7.7 & - \\
\hline & absolute number & & 22 & 11 & 7 \\
\hline & $\%$ & III & 60.5 & 84.6 & 41.2 \\
\hline & absolute number & IV & 8 & 1 & 6 \\
\hline & $\%$ & iv & 21.1 & 7.7 & 35.4 \\
\hline & absolute number & $\mathrm{V}$ & 6 & - & 3 \\
\hline & $\%$ & $\mathrm{v}$ & 15.8 & - & 17.5 \\
\hline & absolute number & $\mathrm{I}$ & - & 1 & - \\
\hline & $\%$ & 1 & - & 2.8 & - \\
\hline & absolute number & II & 3 & 1 & - \\
\hline & $\%$ & II & 7 & 2.8 & - \\
\hline & absolute number & & 31 & 28 & 34 \\
\hline Shoemakers & $\%$ & III & 72.1 & 80 & 72.3 \\
\hline & absolute number & IV & 4 & 3 & 7 \\
\hline & $\%$ & IV & 9.3 & 8.6 & 14.9 \\
\hline & absolute number & $\mathrm{V}$ & 5 & 2 & 6 \\
\hline & $\%$ & $\mathrm{v}$ & 11.6 & 5.8 & 12.8 \\
\hline
\end{tabular}




\begin{tabular}{|c|c|c|c|c|c|}
\hline 1 & 2 & 3 & 4 & 5 & 6 \\
\hline \multirow{10}{*}{ Butchers } & absolute number & \multirow{2}{*}{ I } & - & 1 & 1 \\
\hline & $\%$ & & - & 20 & 16.7 \\
\hline & absolute number & \multirow{2}{*}{ II } & 1 & - & - \\
\hline & $\%$ & & 4.2 & - & - \\
\hline & absolute number & \multirow{2}{*}{ III } & 14 & 2 & 4 \\
\hline & $\%$ & & 58.3 & 40 & 66.6 \\
\hline & absolute number & \multirow{2}{*}{ IV } & 7 & 2 & - \\
\hline & $\%$ & & 29.2 & 40 & - \\
\hline & absolute number & \multirow{2}{*}{ V } & 2 & - & 1 \\
\hline & $\%$ & & 8.3 & - & 16.7 \\
\hline \multirow{10}{*}{ Others } & absolute number & \multirow{2}{*}{ I } & 1 & 1 & 1 \\
\hline & $\%$ & & 5.3 & 3.1 & 0.7 \\
\hline & absolute number & \multirow{2}{*}{ II } & 1 & 1 & 1 \\
\hline & $\%$ & & 5.3 & 3.1 & 0.7 \\
\hline & absolute number & \multirow{2}{*}{ III } & 12 & 24 & 115 \\
\hline & $\%$ & & 63.3 & 75 & 77.7 \\
\hline & absolute number & \multirow{2}{*}{ IV } & 2 & 1 & 17 \\
\hline & $\%$ & & 10.5 & 3.1 & 11.5 \\
\hline & absolute number & \multirow{2}{*}{ V } & 3 & 5 & 14 \\
\hline & $\%$ & & 15.6 & 15.7 & 9.4 \\
\hline
\end{tabular}

Note: For total percentage, see below Table 5.

Sources: CSHAUK, Fund 57, Register 1, Case 278: 2-303; Voloshyn, Poltava City, 44-505; "Rumjancevsjkyj opys", 3-197.

Table 5. Structure of craftsman households according to family types (by Peter Laslett's classification)

\begin{tabular}{|c|c|c|}
\hline Family types & Absolute number & $\%$ \\
\hline I & 18 & 3.4 \\
\hline II & 13 & 2.6 \\
\hline III & 358 & 68.7 \\
\hline IV & 61 & 11.7 \\
\hline $\mathrm{V}$ & 71 & 13.6 \\
\hline Total & 521 & 100.0 \\
\hline
\end{tabular}

Source: CSHAUK, Fund 57, Register 1, Case 278: 2-303. Voloshyn, Poltava City, 44-505; "Rumjancevsjkyj opys", 3-197.

The nuclear family dominated in the urban society of the Hetmanate. This index was $68.7 \%$ among craftsmen families (Tables 4,5 ). $64.3 \%{ }^{34}$ of families in

${ }^{34}$ As a comparison, I should mention that, according to Yuriy Voloshyn's calculation, in Poltava, a decade after the Rumiantsev Census in 1775, the typology of craftsmen families had changed 
Poltava were nuclear, $74.8 \%$ in Pereiaslav, and $66.6 \%$ in Nizhyn. This index is similar to other cities of the Hetmanate $\left(73.6 \%{ }^{35}\right)$ and in mid-late 18th-century Europe: Wielun $-71.6 \%$, Corfe Castle (England) $-76 \%{ }^{36}$, Maria Langegg (Austria) (1778-1848) - 76.5\%, Heiligeneich (Austria) (1778-1848) - 79.3\% $\%^{37}$, Cracow (1791) - 67.0\%, Warsaw (1791) - 66.4\%, Radziejow (1791) - 79.1\%, Olkush (1791) $-79.4 \%{ }^{38}$, etc.

A detailed review of every specialty demonstrates interesting differences. For example, there was an impressive dissimilarity among weaver families in various cities: nuclear families totally dominated in Pereislav at $85.7 \%$, while in Nizhyn, extended families were more common, at $38.5 \%$, than nuclear families, at $30.7 \%$. Nuclear families prevailed (over 50\%) among smiths, shoemakers and other specialties. Nevertheless, there were only $30.8 \%$ and $40 \%$ of nuclear families correspondingly among tailors in Nizhyn and butchers in Pereiaslav.

Multifocal families on average came a distant second, dominant among them those with descending cores, at $13.6 \%$. In Pereiaslav and Poltava, extended families came in second place, with multifocal families in third place. For example, the biggest craftsman family studied was the family of the Nizhyn weaver Dmytro Ohorodnyk (23 people). 80-year-old Dmytro had four married sons and two unmarried adult grandsons. All of them lived together and wove in the guild.

Several remarks should be made about the specific ages in this family. Firstly, there are a certain number of them (6 adults in one family) whose age is "a round number". According to the observations of I. Serdiuk, the number of such people in Nizhyn after the Rumyantsev Census was abnormally high (27.8\%), so it is likely that some of them had forgotten their age and had rounded it off. ${ }^{39}$ The accuracy of the author also influenced the precision of the information regarding age. Consequently, either a real disproportion, or a smaller one that grew due to rounding off, can explain the disparity of 10 years between the head of the family Dmytro and his wife Olena. Secondly, if the age of the fourth son Yakiv was exactly 24 and his wife Feodosiia was 35, he definitely could not have been the father of Vasyl, who was 19. Therefore, we either have a mistake, or the fact that

\footnotetext{
very little: $1^{\text {st }}$ type $-1.3 \% ; 2^{\text {nd }}-0.6 \% ; 3^{\text {rd }}-72.7 \% ; 4^{\text {th }}-12.3 \% ; 5^{\text {th }}-13.1 \%-$ Yuriy Voloshyn, "Naselennia domohospodarstv i struktura rodyn meshkantsiv Poltavy druhoi polovyny XVIII st. (za materialamy spovidnykh rozpysiv)", Socium 10 (2013): 46.

${ }^{35}$ Voloshyn, Sakalo, "Naselenist", 292.

${ }^{36}$ Schmidt, "Wielkość", 153, table 3.

${ }^{37}$ Jim Brown, "The Stem Family in Lower Austria, 1788-1848: Demographic and Economic Constraints", in: The Stem Family in Eurasian Perspective. Revisiting House Societies, 17th-20th centuries, eds. Antoinette Fauve-Chamoux, Emiko Ochiai (Bern: Peter Lang, 2009), 140.

${ }^{38}$ Kuklo, Demografia, 242, 359, table 74.

${ }^{39}$ Serdiuk, Polkovykh horodov obyvateli, 79-84.
} 
Vasyl was Feadosiia's son, whom she had given birth to at 16, probably before she got married.

Diagram 1. Family of Nizhyn weaver Dmytro Ohorodnyk (1766)

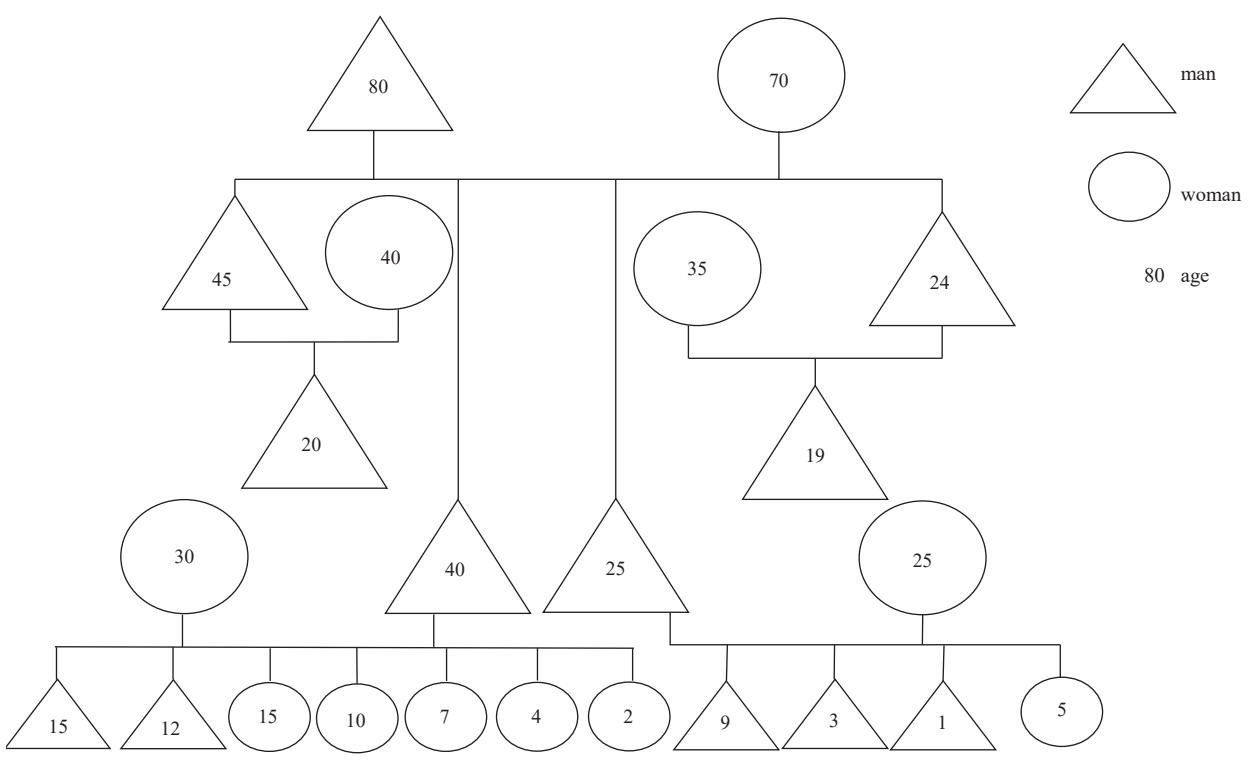

Source: “Rumjancevsjkyj opys”, 169, 170.

Extended families were in third place; communities with side extension came top at just under $11.7 \%$. Unstructured families and unmarried people or widowers were in fourth place, with $1.4 \%$. The last index does not coincide with Yuriy Voloshyn's data, as he stated unstructured families to be the least spread $(1.6 \%)^{40}$. Evidently, this might be connected with the importance of help given in the workplace.

Other untypical situations include a substantial percentage of unstructured smith communities in Pereislav, at $16.7 \%$; an appreciable number of extended tailor households in Nizhyn, at 26.9\%; and a limited number of extended and multifocal butcher families.

In most cases men owned households in artisan society. The number of property owners who were widows was very small. According to Yuriy Voloshyn's calculation, no artisan widow was a head of the household in Poltava, although

${ }^{40}$ Voloshyn, Sakalo, "Naselenist”, 293. 
widows made up $14.8 \%$ of owners in the city ${ }^{41}$. According to my own calculation, such households existed in other two cities. In Pereiaslav there were 5 widow households (that is $5.2 \%$ of artisan households). Two of these owners were artisans themselves, and one even belonged to a baking guild. Others had artisan relatives that lived at their yards. The number of widow households in Nizhyn was a little higher, at 42 in total (17.6\%): artisan widows, who were bakers, cutters and skinners, headed 29 households; in 7 cases except for the owner, men, who were relatives and artisans, also lived there; in 6 cases only artisan relatives did. As a more detailed description, all the artisan households in Nizhyn are classified according to the following scheme (Table 6).

Table 6. Structure of family households in Nizyn 1766

(by Peter Laslett and and Cezary Kuklo's classification)

\begin{tabular}{|c|c|c|c|c|}
\hline Category & Class & Description & $\begin{array}{l}\text { Absolute } \\
\text { number }\end{array}$ & $\%$ \\
\hline \multirow{2}{*}{ Solitaries } & $1 \mathrm{a}$ & widows and widowers & 8 & 3.0 \\
\hline & $1 \mathrm{~b}$ & single or unknown marital status & 6 & 2.2 \\
\hline \multirow{2}{*}{ No family } & $2 \mathrm{a}$ & single brothers and sisters who live together & 1 & 0.4 \\
\hline & $2 b$ & other blood relatives who live together & 2 & 0.8 \\
\hline \multirow{4}{*}{$\begin{array}{l}\text { Nuclear fam- } \\
\text { ilies }\end{array}$} & $3 a$ & married couples without children & 15 & 5.6 \\
\hline & $3 b$ & married couples with children & 138 & 51.5 \\
\hline & $3 \mathrm{c}$ & widows with children & 10 & 3.7 \\
\hline & $3 d$ & widowers with children & 13 & 4.9 \\
\hline \multirow{3}{*}{$\begin{array}{l}\text { Extended } \\
\text { families }\end{array}$} & $4 a$ & upward extended families & 12 & 4.5 \\
\hline & $4 \mathrm{~b}$ & downward extended families & 11 & 4.1 \\
\hline & $4 \mathrm{c}$ & horizontal (sideways) extended families & 14 & 5.2 \\
\hline \multirow{4}{*}{$\begin{array}{l}\text { Multifocal } \\
\text { families }\end{array}$} & $5 \mathrm{a}$ & families with upward secondary nuclei & 6 & 2.2 \\
\hline & $5 b$ & families with downward secondary nuclei & 10 & 3.7 \\
\hline & $5 \mathrm{c}$ & $\begin{array}{l}\text { widowed father/mother with minimum two } \\
\text { married children }\end{array}$ & 6 & 2.2 \\
\hline & $5 \mathrm{~d}$ & $\begin{array}{l}\text { families of brothers and sisters who live to- } \\
\text { gether or other sideways blood relatives }\end{array}$ & 16 & 6.0 \\
\hline Total & $x$ & $\times$ & 268 & 100.0 \\
\hline
\end{tabular}

Source: "Rumjancevsjkyj opys", 3-197.

There were many relatives, except for fathers and sons, in the same guild. I would like to mention that the degree of relationship differs depending on the specialties. The lowest is for shoemakers and tailors; the highest is for smiths, coopers and potters. For example, there were many relatives among the Poltava

\footnotetext{
${ }^{41}$ Voloshyn, Kozaky, 201, 206.
} 
smiths - there are three cases where brothers lived together, and held property in common, as one of the smith brothers possessed a yard, and the other a smithy.

\section{Conclusions}

1. Craftsmen households in Hetmanate cities did not form separate guild blocks or streets. They mainly lived in their own yards, with only a few of them living in yardless houses: $4.9 \%$ of craftsmen families in Poltava, $18.7 \%$ in Pereiaslav, and $0.8 \%$ in Nizhyn. From one to three houses, a pantry and other household outbuildings were located in the yards. Most of the craftsmen possessed yards with the simplest building structure, which included one house (50.2\%) or a house with a pantry $(16.1 \%)$. Therefore, they did not have a special area for workshops, excluding smithies, which were placed outside households.

2. According to the stated demographic indexes, the craftsman population in Hetmanate cities coincides with the European model. First place was taken by the nuclear family (68.7\%). Multiple family households occupy second place with $13.6 \%$ and extended families occupy third place with $11.7 \%$. Consequently, we can observe the prevalence of the nuclear family over the multifocal family that dominated among the agrarian population and craftsmen in Central Europe until the $19^{\text {th }}$ century. The situation occurred when adult sons became master craftsmen, got married, and stayed in their parents' house, creating complicated households with older members the heads. When the father died, his son became the head of household, turning it into an extended one.

3. The size of craftsman families was small and in total was 4.5 for three cities: Pereiaslav, 4.1, Poltava, $4.3^{42}$ and Nizhyn, 5.0. This size was lower than the size of the population in Cossack and peasant households in the Hetmanate cities. The size of the craftsman household population was correspondingly higher, at 5.8 people, while in Pereiaslav, it was 5.2, in Nizhyn, 6.2, and in Poltava, 5.9. Workers, apprentices, journeymen, relatives and others could also live in households with a family. Simultaneously master craftsmen taught from one to four apprentices, who lived with a family for 1 to 10 years. The size of artisan households of different professions shows that despite the regional diversity, the butchers' yards were not highly-populated (average size - 4.2, 4.9 people), and the yards of weavers $(5.6,5.9)$ were the most crowded.

${ }^{42}$ Voloshyn, Kozaky, 183. 


\section{Bibliography}

\section{Sources}

Central State Historical Archive of Ukraine in Kiev - Fund 57, Register 1, Case 278; Fund 57, Register 2, Case 1.

“Rumjancevsjkyj opys m. Nizhyna 1766 r.” Nizhynsjka starovyna: zbirnyk reghionaljnoji istoriji ta pam' jatkoznavstva 10 (2008), 7: 3-197.

Voloshyn, Yuriy, ed. Poltava City in Rumyantsev Register of Little Russia in 1765-1769. Kyiv: Our time, 2012.

\section{References}

Brown, Jim. "The Stem Family in Lower Austria, 1788-1848: Demographic and Economic Constraints". The Stem Family in Eurasian Perspective. Revisiting House Societies, 17th-20th centuries, eds. Antoinette Fauve-Chamoux, Emiko Ochiai, 140149. Bern: Peter Lang, 2009.

Kazimirov, Dmytro. Features of Forming and Developing Company Structures in Hetmanate in the Second Half of the 17-18 ${ }^{\text {th }}$ Century (Based on Materials of Mena's Company/Squadron of Chernihiv Regiment). PhD Thesis. Kyiv: The Institute of the History of Ukraine of the National Academy of Sciences of Ukraine, 2012.

Kapralj, Myron. Ljudy korporaciji: Ljvivsjkyj shevsjkyj cekh u XVII-XVIII st. Ljviv: ProstirM, 2012.

Klymenko, Pylyp. Misto y terytoriia za Hetmanshchyny 1654-1764. Kyiv: UAN, 1926.

Kohut, Zenon. Russian Centralism and Ukrainian Autonomy. Imperial Absorption of the Hetmanate, 1760s-1830s. Cambridge, MA: Harvard University Press, 1990.

Kovalenko, Oksana. Poltava XVII-XVIII st.. Kyiv: PP Oleh Filiuk, 2015.

Kovaljsjkyj, Igor. “Gheneraljnyj opys 1765-1769 rr. - dzherelo dlja vyvchennja socialjno-ekonomichnykh vidnosyn na Livoberezhnij Ukrajini”. Ukrajinsjkyj istorychnyj zhurnal 2 (1962): 97-103.

Kuklo, Cezary. Demografia Rzeczypospolitej przedrozbiorowej. Warszawa: Wydawnictwo DIG, 2009.

Laslett, Peter. "Family and Household as Work and Kin Group: Areas of Traditional Europe Compared". In: Family Forms in Historic Europe, eds. Richard Wall, Jean Robin, Peter Laslett, 513-564. Cambridge: Cambridge University Press, 1983.

Maksimovich, Grygoriy. Deyatelnost Rumyantseva-Zadunayskogo po upravleniyu Malorossiey”. Nezhin: Typography of Melenevskiy, 1913.

Perkovskiy, Arnold. “O lyudnosti ukrainskogo dvora i velichine semi vo vtoroy polovine XVIII veka (po materialam Rumyantsevskoy opisi i tserkovnoy statistiki)”. Problemy istoricheskoy demografii SSSR (1977): 104-111.

Putro, Oleksiy. “Gheneraljnyj opys 1765-1769 pp. jak dzherelo dlja vyvchennja socialjno-ekonomichnykh vidnosyn na Livoberezhnij Ukrajini u drughij polovyni XVIII st." Ukrajinsjkyj istorychnyj zhurnal 7 (1982): 143-149. 
Schmidt, Joanna. "Wielkość i struktura gospodarstw domowych w Siemiatyczach w 1807 roku”. Przeszłość Demograficzna Polski 39 (2017): 141-166.

Serdiuk, Ihor. Polkovykh horodov obyvateli: istorko-demohrafichna kharakterystyka miskoho naselennia Hetmanshchyny druhoi polovyny XVIII st. Poltava: ASMI, 2011.

Serdjuk, Ihor. "Rumjancevsjkyj opys Malorosiji jak dzherelo vyvchennja demoghrafichnykh kharakterystyk mist Ghetjmanshhyny". Istorychna pam' jatj 3 (2008): 144-152.

Szołtysek, Mikołaj. "Three Kinds of Preindustrial Household Formation System in Historical Eastern Europe: A Challenge to Spatial Patterns of the European Family". The History of the Family 13 (2008), 3: 225-257.

Voloshyn, Yuriy. Kozaky i pospolyti. Miska spilnota Poltavy druhoi polovyny XVIII st. Kyiv: K.I.S., 2016.

Voloshyn, Yuriy. "Naselennia domohospodarstv i struktura rodyn meshkantsiv Poltavy druhoi polovyny XVIII st. (za materialamy spovidnykh rozpysiv)". Socium 10 (2013): 31-50.

Voloshyn, Yuriy, Oleksandr Sakalo. "Naselenist domohospodarstv i struktura rodyn". In: Ukrainskyi Hetmanat: narysy istorii natsionalnoho derzhavotvorennia XVIIXVIII st., eds. Valeriy Smolii, Olena Bachynska, Viktor Horobets, Oleksandr Hurzhii, Valentyna Matiakh, Yuriy Mytsyk, Valeriy Stepankov, Yaroslav Fedoruk, Taras Chukhlib, 274-303. Vol. 2. Kyiv: Instytut istorii Ukrainy, 2018.

Voloshyn, Yuriy. "Household Composition and Family Structures of Ukrainian Cossacks in the Second Half of the Eighteenth Century". The History of the Family 20 (2015), 1: $141-157$.

Voloshyn, Yuriy. Rozkolnytski slobody na terytorii Pivnichnoi Hetmanshchyny u XVIII st. (istoryko demohrafichnyi aspekt). Poltava: ASMI, 2005.

\section{Family Structures and Population of Craftsman Households in Cossack Ukraine in the Second Half of the $18^{\text {th }}$ Century}

\section{Summary}

The aim of the article is to observe the demographical characteristics of the Cossack Hetmanate (an autonomous Cossack territory situated on the Left Bank of the Dnieper River), guild craftsman families and households in the second half of the $18^{\text {th }}$ century in the cities of Poltava, Pereiaslav and Nizhyn. The index and size of the craftsman household population, and their family densities are analyzed, their family types and household development structure are defined on the basis of the General Description of the Leftbank Ukraine of 1765-1766 ("Rumyantsev Census"). Craft specialization was considered for this purpose - calculations were made separately for the most widespread crafts, given in all cities: weaving, blacksmithing, tailoring, shoemaking and butchering. It was determined that artisans settling in the Hetmanate cities were of a dispersive character, with 
guild craftsmen living in their own yards (99.2-81.3\%). These households had simple residential accommodation, which included one house (50.2\%) or a house with a pantry (16.1\%). This means that artisans did not have a special space for workshops, excluding smithies located outside households. According to the demographic indexes, the craftsman population of Hetmanate cities fits the western European model, as the leading position belonged to the nuclear family (68.7\%). Multifocal family occupies second place with $13.6 \%$ and the extended family occupies third place with $11.7 \%$. On average, the population of the craftsman households was 5.8 people, with the density of their families 4.5 persons. This size was smaller than the Cossack and peasant ("pospolyti") household size in the Hetmanate cities. Workers, apprentices, journeymen, relatives or other persons could also live in a household with a family. Master craftsmen taught from one to four apprentices simultaneously. Household size for artisans of different professions shows that, despite the regional diversity, butchers' yards were sparsely populated, and the yards of weavers and shoemakers were the most crowded.

\section{Struktura rodziny i populacji gospodarstw domowych rzemieślników na kozackiej Ukrainie w drugiej połowie XVIII wieku}

\section{Streszczenie}

Celem artykułu było ukazanie cech demograficznych rodzin rzemieślników cechowych i ich gospodarstw domowych w Hetmanacie Kozackim (kozackie terytorium autonomiczne położone na lewym brzegu Dniepru) w drugiej połowie XVIII wieku na przykładzie miast Poltava, Pereiaslav i Nizhyn. Przeanalizowano wskaźniki i wielkość populacji rzemieślników i ich rodzin, typy rodzinne i strukturę gospodarstw domowych na podstawie Generalnego Opisu Lewobrzeżnej Ukrainy z lat 1765-1766 („Spis ludności Rumiancewa"). W tym celu uwzględniono czynnik specjalizacji rzemieślniczej - obliczenia przeprowadzono osobno dla najbardziej rozpowszechnionych rzemiosł występujących we wszystkich miastach: tkactwa, kowalstwa, szewstwa i rzeźnictwa. Ustalono, że rzemieślnicy osiedli w miastach Hetmanatu byli rozproszeni, a rzemieślnicy cechowi zamieszkiwali we własnych domach z podwórzem i innymi przyległymi zabudowaniami o charakterze mieszkalnym lub gospodarczym (,dvor”) (99,2-81,3\%). Tego rodzaju gospodarstwa domowe funkcjonowały w prostej strukturze zabudowy, która obejmowała jeden dom $(50,2 \%)$ lub dom ze spiżarnią (16,1\%). Oznacza to, że rzemieślnicy nie mieli specjalnego miejsca na warsztaty, z wyjątkiem kuźni zlokalizowanych poza gospodarstwami domowymi. Na podstawie wskaźników demograficznych można stwierdzić, że ludność rzemieślnicza miast Hetmanatu wpasowywała się w model zachodnioeuropejski, jako że wiodąca pozycja należała do rodziny nuklearnej (68,7\%). Rodzina złożona zajmowała drugie miejsce - 13,6\%, a rodzina rozszerzona plasowała się na trzecim $11,7 \%$. Przeciętnie gospodarstwo domowe rzemieślnicze liczyło sobie 5,8 osoby, a obsada 
rodzin $-4,5$ osoby. Wielkość ta była mniejsza w porównaniu z kozackimi i chłopskimi (,pospolyti”) gospodarstwami domowymi w miastach Hetmanatu. Pracownicy, uczniowie, czeladnicy, krewni i inne osoby mogły również mieszkać w gospodarstwie domowym ze swoją rodziną. Mistrzowie przyuczali od jednego do czterech uczniów jednocześnie. Wielkość gospodarstw domowych rzemieślników różnych zawodów pokazuje, że pomimo różnorodności regionalnej domostwa („,dvory”) rzeźników nie były silnie obsadzone, a domostwa tkaczy i szewców były najbardziej zagęszczone pod względem obsady osobowej. 